\title{
Sociale cohesie in gentrificerende arbeiderswijken van Amsterdam-Noord
}

\author{
Linda van de Kamp \& Saskia Welschen ${ }^{*}$
}

\section{Inleiding}

De krapte in het Amsterdamse woningaanbod en de bijbehorende stijgende huuren huizenprijzen geven steeds meer mensen reden tot zorg over het inclusieve karakter van de stad (Milikowski, 2018). Biedt de stad vooral ruimte aan groepen die al kansrijk zijn, en steeds minder aan kansarmen? En wat doet de toename van welvarendere bewoners met de sociale cohesie van zogenoemde kwetsbare wijken ${ }^{1}$ Voelen mensen zich nog wel thuis in hun buurt?

De economische en culturele opwaardering van kwetsbare stadswijken door de komst van kapitaalkrachtige nieuwe bewoners en gebruikers, oftewel gentrificatie, gaat in allerlei steden in de wereld vaak gepaard met de verdrijving van bewoners met een lagere inkomenspositie uit de wijk (Lees, 2008; Marcuse, 1985). In Amsterdam zorgen de wettelijk vastgelegde huurdersbescherming en het grote aandeel sociale huurwoningen (ruim 40 procent) voor weinig directe fysieke verdringing (Van Gent, 2013). Nederland, en daarmee ook Amsterdam, kent een sociaaldemocratische traditie van het tegengaan van inkomenssegregatie door 'een gemengd woningaanbod, de aanwezigheid van een grote en daardoor minder gestigmatiseerde sociale huursector en de gewoonte om in nieuwbouwwijken een ferm aandeel sociale huurwoningen te bouwen' (Vermeij \& Kullberg, 2015, 11). ${ }^{2}$ Ondanks de toegenomen liberalisering van de woningmarkt draagt het woningmarktbeleid van Amsterdam eraan bij dat buurten in de praktijk veelal gemengd zijn wat betreft huisvestingsvormen - koop, huur en vrije sector (Hochstenbach, Musterd \& Teernstra, 2015). In de praktijk wonen in steeds meer Amsterdamse buurten de zogenaamde 'gentrifiers' en 'non-gentrifiers' naast elkaar. ${ }^{3}$

Wél leidt het mengen van bewoners in kwetsbare wijken tot ervaringen van indirecte en culturele verdringing onder langdurig ingezetenen die minder kapitaalkrachtig zijn (Paton, 2014; Shaw \& Hagemans, 2015). Een deel van de oorspronkelijke bewoners blijft weliswaar in het krimpende aandeel sociale huurwoningen wonen, maar ziet de omgeving veranderen. De wijk ondergaat de gevolgen van gentrificatie; inwoners met een andere inkomenspositie trekken de wijk in, het commerciële aanbod in de wijk verandert en het voorzieningenniveau wordt aangepast aan de nieuwe bevolkingssamenstelling.

Daarom kijken we in deze bijdrage naar hoe oorspronkelijke bewoners ${ }^{4}$ in verschillende gentrificerende tuindorpen in Amsterdam-Noord (kortweg Noord) de veranderingen in hun buurt waarderen en ervaren in termen van sociale cohesie -

* Dr. Linda van de Kamp is werkzaam aan de afdeling Sociologie van de Universiteit van Amsterdam. Dr. Saskia Welschen is senior onderzoeker aan de Hogeschool van Amsterdam en zelfstandig onderzoeker. 
met andere woorden: in hoeverre mensen zich thuis voelen in hun veranderende buurt en zich verbonden voelen met anderen (Duyvendak, 2011). ${ }^{5}$

In de loop van deze eeuw is begonnen met de verkoop van sociale huurwoningen in de Noordse wijken als onderdeel van het landelijke stedelijke vernieuwingsbeleid, gericht op het 'sociaal mengen' in kwetsbare wijken (Engbersen, Snel \& Weltevrede, 2005; Kleinhans, Veldboer \& Duyvendak, 2019; Uitermark, 2014; zie ook Bridge, Butler \& Lees, 2012). Dit proces van door de overheid gestuurde gentrificatie (Hochstenbach, 2017) verandert de sociale samenstelling van wijken met de expliciete gedachte dat de komst van kapitaalkrachtige bewoners positieve effecten heeft voor met name kwetsbare bewoners. Zoals de raad van het voormalige ministerie van Volkshuisvesting, Ruimtelijke Ordening en Milieubeheer adviseerde in Stad en stijging (VROM-raad, 2006, 3): de stedelijke middenklasse 'vormt het sociaal kapitaal van de stad en is nodig voor de stijging van anderen. Om deze sociale stijgers aan de stad te binden, moeten extra kwaliteiten aan de wijk worden toegevoegd die aansluiten bij hun wensen.' Eén verwacht positief effect van het sociaal mengen in buurten is dat armere bewoners via de nieuwe middenklassebewoners hun sociaal kapitaal vergroten, waardoor ze in potentie toegang krijgen tot nieuwe hulpbronnen (De Jong, Omlo \& Kooiman, 2015; zie ook Portes, 1998).

Deze gedachte is onder andere terug te leiden tot het bekende werk van Robert Putnam (2000), die stelde dat sociale cohesie in sterke mate afhankelijk is van 'bonding and bridging social capital'. Samenbindend sociaal kapitaal (bonding social capital) heeft betrekking op sociale netwerken van mensen die op elkaar lijken: hechte verbanden tussen familie, vrienden en gelijkgestemden. Overbruggend sociaal kapitaal (bridging social capital) gaat juist over de verbanden tussen individuen die van elkaar verschillen en op grotere afstand van elkaar staan. Op beleidsniveau wordt het antwoord op een eventuele afname van sociale cohesie in stadswijken vaak gezocht op het niveau van bridging kapitaal: in het verbinden van buren die van elkaar verschillen, in dit geval in het verbinden van oorspronkelijke bewoners met de nieuwe bewoners (Veldboer, Duyvendak \& Bouw, 2007; Kullberg, 2009). Verschillende beleidsinterventies richten zich op het verbinden van bewoners met diverse sociaaleconomische en culturele achtergronden om tenminste het begrip voor elkaar te bevorderen. Een achterliggende doelstelling is om kwetsbare oorspronkelijke bewoners te 'verheffen' door contact met kapitaalkrachtige bewoners (zie ook Kleinhans e.a., 2019).

We kijken daarom in deze bijdrage specifiek naar hoe oorspronkelijke bewoners deze interventies ervaren. Op basis van ons onderzoeksmateriaal kijken we kritisch naar het idee van 'bridging kapitaal' dat ten grondslag ligt aan de verschillende sociale activiteiten die worden georganiseerd. Vervolgens bespreken we het belang van 'bonding kapitaal' of de onderlinge verbondenheid voor oorspronkelijke bewoners. Uit onze interviews en participerende observaties blijkt dat activiteiten in 'eigen kring' in belangrijke mate bijdragen aan het thuisgevoel in de wijk. Ten slotte staan we stil bij de rol van sociale ruimtes en ontmoetingsplaatsen in het creëren van een thuisgevoel in de buurt en de stad. Uit onze analyse vloeit het inzicht voort dat het zinvoller lijkt om te streven naar lichtere vormen van ontmoeting tussen mensen die van elkaar verschillen. We bespreken daarom tot slot 
hoe verschillende sociale ruimtes mogelijkheden bieden voor die lichtere vormen van ontmoeting zonder dat zij direct gericht zijn op sterke verbindingen tussen mensen in de buurten.

De bevindingen die wij hier presenteren, zijn gebaseerd op verschillende opeenvolgende onderzoeksprojecten in de voormalige arbeiderswijken of tuindorpen van Amsterdam-Noord in de periode 2010 tot 2017. Door middel van participerende observaties, focusgroepen en interviews keken wij onder andere naar hoe bewoners zich verhouden tot hun buurt, waarom zij zich er wel of niet thuis voelen, hoe zij veranderingen duiden, en waar ze eventuele buurtgenoten ontmoeten. Saskia Welschen heeft in 2013 en 2014 in opdracht van de Open Society Foundations uitgebreid kwalitatief onderzoek (interviews en focusgroepen) gedaan in de buurten Tuindorp Buiksloot ('Het Blauwe Zand') en Floradorp in Oud-Noord in Amsterdam-Noord. Het onderzoek richtte zich op thuisgevoel en maatschappelijke participatie onder oorspronkelijke bewoners in voormalige arbeiderswijken in Amsterdam en resulteerde in de publicatie White Working Class Communities in Amsterdam (Welschen, 2014). Verschillende citaten die in dit artikel worden opgevoerd, zijn verzameld binnen dit onderzoeksproject. In 2017 voerde Welschen een actualisatie van dit onderzoek uit. Daarnaast is zij sinds 2018 vanuit de Hogeschool van Amsterdam binnen de werkplaats Sociaal Domein betrokken bij verschillende onderzoeken in het sociaal domein in Amsterdam-Noord (in OudNoord, Tuindorp Oostzaan en de Molenwijk).

In 2008 verhuisde Linda van de Kamp naar een van de tuindorpen in AmsterdamNoord en raakte betrokken bij verschillende buurtprojecten die gesubsidieerd werden door de gemeente Amsterdam en een woningbouwcorporatie. Op verschillende momenten maakte zij als cultureel antropoloog aantekeningen van wat er gebeurde. Naar aanleiding daarvan heeft zij in de periode 2012-2014 als postdoctorale onderzoeker bij de Universiteit van Tilburg etnografisch onderzoek gedaan bij buurtprojecten in verschillende buurten van Oud-Noord. Van 2015 tot 2017 heeft zij in het kader van haar onderzoeksproject 'Yoga, Bingo en Gebed in Stedelijke Regeneratie Gebieden' bij de Universiteit van Amsterdam etnografisch onderzoek gedaan in verschillende Noordse tuindorpen in relatie tot de herontwikkeling van de omliggende voormalige industriële gebieden (Van de Kamp 2018, 2019). ${ }^{6}$ Bij de presentatie van het onderzoeksmateriaal hieronder refereren we zo nodig naar wie de onderzoeker was (Welschen of Van de Kamp) en de specifieke periode of datum.

\section{Stedelijke veranderingen in Amsterdam-Noord}

Amsterdam-Noord is in de afgelopen jaren in rap tempo veranderd door renovatie, nieuwbouw en de komst van vele creatieve en culturele voorzieningen (Hoekstra, Van Gent \& Boterman, 2018; Savini \& Dembski, 2016; Van de Kamp, 2018). Daarbij vormen de voormalige industriegebieden en de vooroorlogse tuindorpen van Oud-Noord vlakbij de rivier het IJ het middelpunt (zie figuur 1). Hier worden de komende jaren ongeveer 10.000 woningen bijgebouwd. ${ }^{7}$ Tegelijk is juist stads- 


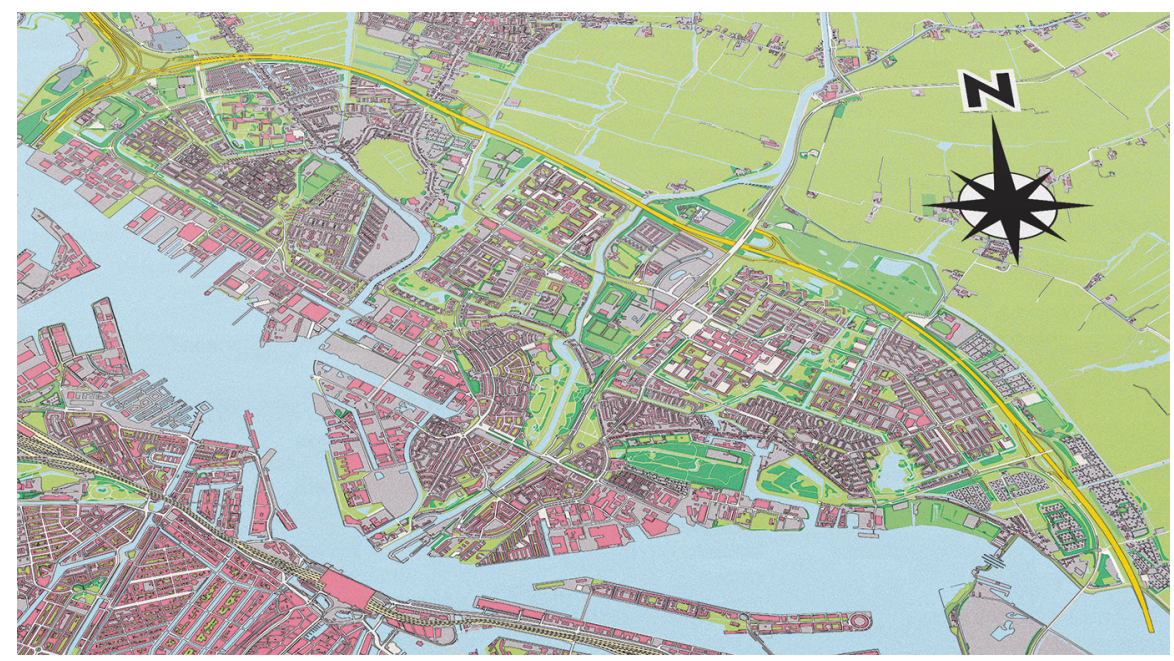

Figuur 1 De rivier het IJ (blauw) scheidt Amsterdam-Noord van de andere stadsdelen () Bureau Scherpenisse

deel Noord een gebied van grote contrasten. Stadsdeel Noord schrijft over OudNoord: 'De armste wijken van de stad liggen direct naast nieuwe wijken waar besteedbaar inkomen en opleidingsniveau gemiddeld vele malen hoger liggen' (Stadsdeel Amsterdam Noord, 2019, 3). Elders schrijft het stadsdeel: 'de oprukkende stad wordt gevoeld in veel wijken in Noord, waar de wereld rondom oude buurten in een rap tempo verandert' (Stadsdeel Amsterdam Noord, 2018, 7). Er vinden dan ook regelmatig heftige discussies plaats op bewonersavonden en op Facebookpagina's over 'yuppen' die Noord overnemen en protesten met slogans als 'Noord moet wijken voor de rijken'.

Amsterdam-Noord was het belangrijkste industriële gebied van Amsterdam gedurende de eerste helft van de twintigste eeuw. Om het groeiend aantal arbeiders te kunnen huisvesten werden er tuindorpen gebouwd door woningbouwverenigingen en de Gemeentelijke Woningdienst Amsterdam. Deze wijken kenmerkten zich door lage woningen met een voor- en een achtertuin en een omgeving met veel groen (zie figuur 2). Elk tuindorp had culturele voorzieningen zoals een buurt- of verenigingsgebouw om de arbeiders te ontwikkelen en de gemeenschapszin te bevorderen (Dercksen \& Verplanke, 2005). Het ontbreken van stedelijk vertier zoals kroegen en de sterke nadruk op de gezinswoning als kern van het leven moesten bijdragen aan de vorming van fatsoenlijke burgers (De Regt, 1995). De samenstelling van de wijken was relatief homogeen, en de woonduur van bewoners lang. Daardoor was er voor stedelijke begrippen een uitzonderlijk groot gevoel van bekendheid met de buurt en de buren, en een sterke lokale identiteit (zie bijvoorbeeld Kok, 2016, 150-151). De sociale controle was groot, en 'zorgen voor elkaar' een vanzelfsprekendheid, aldus oude bewoners (vergelijk Ypeij, Snel \& Engbersen, 2002, 75-89, 129-145). 


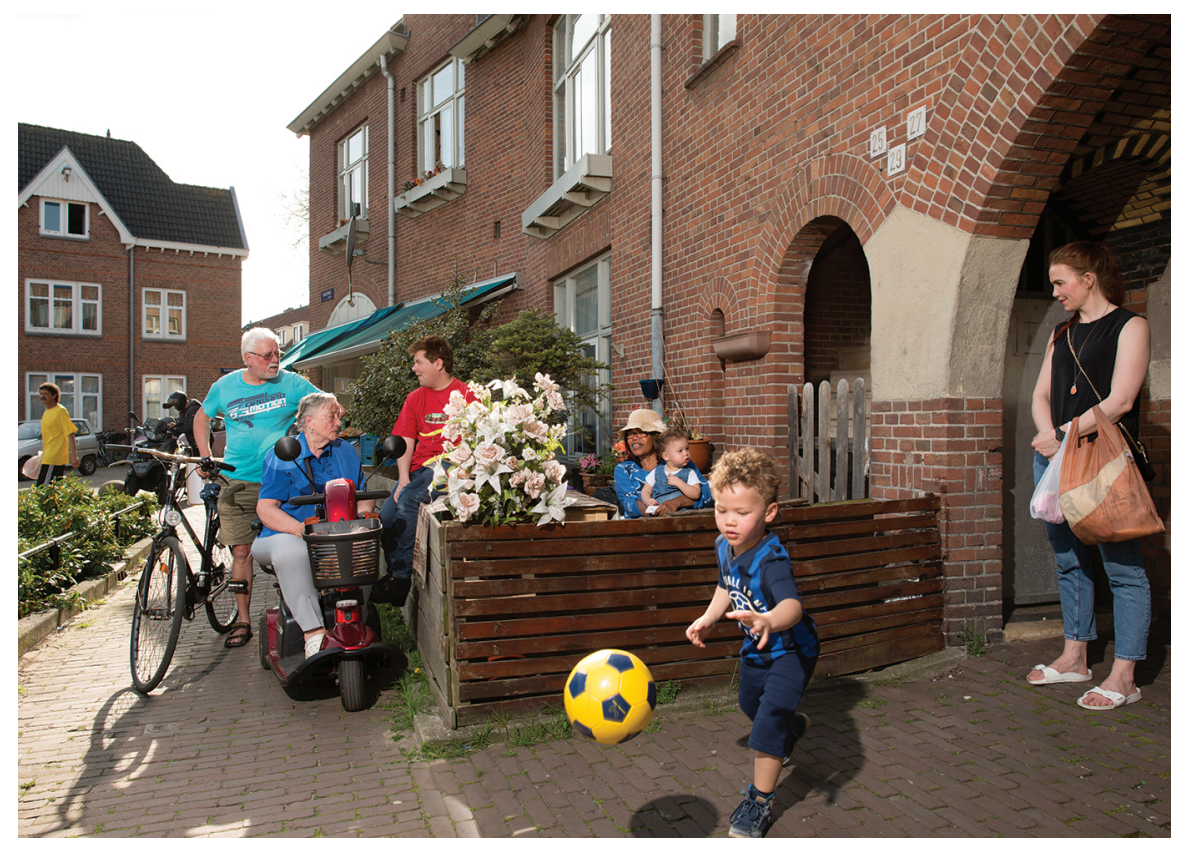

Figuur 2 Oud-Noord, Serie Buurtbanden Amsterdam-Noord (@ Rufus de Vries)

Bewoners die in de tuindorpen zijn opgegroeid en/of hun kinderen er hebben grootgebracht, vertelden ons hoe zij actief waren in hun 'dorp'. Ze participeerden in het verenigingsleven (kaart-, voetbal- en huurdersverenigingen), in de strijd die ze voerden tegen autoriteiten over het onderhoud van de huizen en de huurprijzen, in het mooi en schoon houden van de ramen en tuintjes, en ze boden onderling hulp. Er bestond rivaliteit tussen de 'dorpen' en er waren regelmatig knokpartijen, zoals oudere bewoners ons in geuren en kleuren vertelden, 'maar je wist wat je aan elkaar had'. ${ }^{9}$ Hierbij distantieerden de geschoolde arbeiders zich ook regelmatig van de minder geschoolde buren en arbeiders (Leydesdorff, 1990). Tegelijk was de collectieve identiteit van alle bewoners het sterk gedeelde gevoel dat ze niet bij 'de stad', bij Amsterdam aan de andere kant van het IJ, hoorden (Leydesdorff, 1990). Die specifieke gevoelens van identiteit bestaan tot op de dag van vandaag. Een deelneemster aan een groepsinterview in Tuindorp Buiksloot ('Het Blauwe Zand') bracht dat onder woorden: 'Ik merk dat de mensen die onder 't IJ wonen, Amsterdam-Noord niet bij de stad vinden horen. Ik voel me wel betrokken bij Amsterdam als stad, maar de liefde is volgens mij niet wederzijds. ${ }^{10}$ Noord werd door veel Amsterdammers als een plek gezien 'waar je nog niet dood gevonden wilde worden' (Kok, 2016, 15). Een paar oude bewoners die in 'de stad' naar school gingen, vertelden hoe zij te horen kregen van hun leerkrachten dat het niks met hen zou worden omdat ze uit Noord kwamen. ${ }^{11}$

Vanaf 1960 verdween er steeds meer industrie en raakten verschillende industriële gebieden en gebouwen in verval. Vele arbeiders raakten werkloos. Tegelijk werd stadsdeel Noord onderdeel van het uitbreidingsplan in de stad en werden er 
nieuwe wijken of tuinsteden gebouwd waar Amsterdammers kwamen te wonen uit de oude stadswijken die gerenoveerd werden. Vanaf dat moment werden de oudere tuindorpen aangeduid als 'Oud-Noord'. Met de stadsvernieuwing in Zuidoost en Nieuw-West in de jaren negentig vond er een nieuwe instroom van mensen plaats in de oude en nieuwere wijken, met name gezinnen met een Marokkaanse, Turkse en Antilliaanse achtergrond; Noord werd multicultureler. Verschillende oudere bewoners vertelden dat het volgens hen vanaf dat moment achteruitging in verschillende buurten doordat bovenop de werkloosheid van de arbeiders een deel van de nieuwkomers hun eigen problemen meenam, zoals drugs en criminaliteit (zie ook Kok, 2016, 158). De buurten werd steeds meer gezien als 'probleemwijken', waar het aan sociale cohesie ontbrak (Uitermark, 2003).

Aan het begin van de huidige eeuw startte een proces van stedelijke herontwikkeling en zijn de voormalige industriële gebieden uitgegroeid tot hotspots voor de creatieve sector (Savini \& Dembski, 2016). Momenteel worden de gebieden getransformeerd naar werk- én woongebieden. Tegenwoordig wordt Noord in allerlei media, toeristische gidsen en top tien lijsten van steden bestempeld als meest hippe gebied van Amsterdam (bijvoorbeeld New York Times, 2012). In de tuindorpen en omliggende omgeving implementeerden de gemeente en woningbouwcorporaties een pro-gentrificatiestrategie; samen met het ontwikkelen van bouwplannen en het verkopen en liberaliseren van sociale huurwoningen werden culturele en commerciële activiteiten gesubsidieerd gericht op het aantrekken van nieuwe middenklassebewoners (Hoekstra e.a., 2018).

Tegelijkertijd hanteert de gemeente Amsterdam, in lijn met het landelijke Grote Stedenbeleid en de wijkaanpak, sinds 2007 een gebiedsgericht beleid met als doel de verbetering van de leefbaarheid in kwetsbare wijken (Van Ankeren, Tonkens \& Verhoeven, 2010; Hoekstra e.a., 2018). In het Actieplan Krachtwijken (2008-2012), gebaseerd op het eerdergenoemde advies van de VROM-raad in Stad en stijging, waren verschillende tuindorpen in Oud-Noord opgenomen: Volewijck, IJplein/Vogelbuurt en Nieuwendam-Noord en ook de uitbreidingswijk Banne Buiksloot (Van Ankeren e.a., 2010, 8). Naast fysieke interventies in de publieke ruimte financierde dit programma bewonersinitiatieven om de leefbaarheid en sociale contacten in de buurten te verbeteren. Toen de nationale overheid het beleid in 2012 beëindigde, continueerde de gemeente Amsterdam onderdelen van het beleid met eigen middelen, de zogenaamde 'Amsterdamse wijkaanpak' (Gemeente Amsterdam, 2012; Kullberg, 2009; vergelijk Hoekstra e.a., 2018, 247). Sinds 2018 voert de gemeente een beleid uit onder de noemer 'ontwikkelbuurten', waarbij extra geïnvesteerd wordt in projecten ter verbetering van het woon- en leefklimaat in 32 buurten die als 'zwak' worden aangemerkt. Ook binnen dit programma zijn buurten in Oud-Noord opgenomen: Volewijck en IJplein/Vogelbuurt. ${ }^{12}$

Als vervolg op het eerdere beleid van 'sociaal mengen' is er in de lokale politiek een grote nadruk op inclusiviteit en sociale integratie tussen bevolkingsgroepen. ${ }^{13}$ In het recente coalitieakkoord van het stadsbestuur wordt 'de verbonden stad' als een van de vijf speerpunten voor de huidige bestuursperiode geschetst. Dit gaat over een stad waarin sprake is van verbondenheid tussen individuen, 
groepen en (sub)culturen, maar ook tussen verschillende gebieden in de stad en stadsdelen (Gemeente Amsterdam, 2018b, 5). Een van de middelen daartoe, aldus het college, is het organiseren van ontmoeting. Daartoe bestaat een breed palet aan concepten voor wijk- en buurtgerichte ontmoetingsplekken om zorg, welzijn en ontmoeting te bevorderen (Ter Avest, 2015, 31).

\section{Sociale cohesie en gevoelens van vervreemding}

Sociale cohesie in buurten duidt veelal op de mate waarin buurtbewoners zich er thuis voelen, elkaar vertrouwen, bereid zijn elkaar te helpen, normen en waarden delen en de gehechtheid van bewoners aan de buurt (onder andere in Hart e.a., 2002; Duyvendak, 2011; Kleinhans \& Bolt, 2010). Het belangrijkste risico van een afname daarvan, dat veelvuldig in de literatuur wordt benoemd, is een vermindering van de leefbaarheid in wijken, zoals verminderende sociale veiligheid, vervuiling van de openbare ruimte en gebrekkige voorzieningen als winkels, buurthuizen en scholen (zie onder meer Knol, Maas-de Waal \& Roes, 2002; Kleinhans \& Bolt, 2010).

Het belang van sociale samenhang en wederzijds vertrouwen tussen buurtbewoners is alleen maar toegenomen tegen de achtergrond van de hervorming van de verzorgingsstaat naar de participatiesamenleving (zie bijvoorbeeld Bredewold e.a., 2018; Tonkens \& De Wilde, 2013). Zowel voor het tot stand komen van collectieve voorzieningen in de buurt als voor de ondersteuning van personen of huishoudens met een hulpvraag is burgerparticipatie inmiddels onontbeerlijk. Met een terugtredende overheid wordt het sociale netwerk in de directe omgeving belangrijker voor de ondersteuning van hulpbehoevende bewoners, zoals kwetsbare ouderen die zelfstandig wonen. Maar juist die laatsten ervaren door de veranderingen in de wijk gevoelens van vervreemding en een afname van hun directe sociale ondersteuningsnetwerk. Het gevolg is dat zij zich soms terugtrekken uit het buurtleven en wegzakken in isolement (Vermeij \& Kullberg, 2015, 20).

Het belang van onderlinge zorgzaamheid en het letten op elkaar werd door veel oorspronkelijke bewoners in het onderzoek van Welschen (2014) in de tuindorpen geschetst. Het baarde bewoners dan ook zorgen dat dit vangnet steeds verder onder druk komt te staan. Een deelneemster aan een groepsinterview in Tuindorp Buiksloot vertelde:

'We houden alles in de gaten, er is veel sociale controle. Maar de nieuwe buren [uit hogere inkomensgroepen] doen dat niet echt. Met de nieuwe bewoners kan je drie weken dood in je bed liggen en dan komen ze nog niet kijken.' ${ }^{14}$

Pinkster $(2017,87)$ beschrijft in haar studie naar de Amsterdamse wijk Betondorp dat oorspronkelijke bewoners zich steeds verder vervreemd voelen door de instroom van zowel hogere inkomensgroepen als prioriteitsdoelgroepen voor sociale huur. In de tuindorpen in Noord beschreven sommige bewoners de komst 
van nieuwe gebruikersgroepen in de buurtvoorzieningen in termen van verdringing, zoals een deelneemster van het groepsinterview in Tuindorp Buiksloot:

'Hier krijgen bijvoorbeeld ieder weekend de kinderen Arabische les in hun eigen taal. En mensen komen dan niet meer naar binnen, er zitten dan een paar hoofddoeken. Alle buurthuizen in Amsterdam Noord zijn bezet in het weekend door buitenlandse mensen, al jaren, om de kinderen in hun eigen cultuur les te geven. (...) Dat pikken ze hier niet, die wonen hier niet.'15

De veranderingen in de buurt leiden tot een toename van de anonimiteit, die in contrast staat met de sterke worteling en collectieve identiteit die oorspronkelijke bewoners van oudsher aan de buurt ('het dorp') verbonden. Zoals blijkt uit de volgende woorden:

'Mijn gevoel van veiligheid is wel veranderd sinds ik de mensen niet meer ken. Als er eerder vreemde types waren, dan wist je wie je moest aanspreken. Ik kan zo benoemen wie er vroeger een scheve schaats reden. Dan sprak je een ouder aan, en dan was het snel weer over. Maar als je elkaar niet meer kent werkt de sociale controle niet meer.' ${ }^{16}$

Een terugkerend thema was het idee dat nieuwe bewoners met een hogere inkomensachtergrond geen tijd nemen om de buurt en de buren te leren kennen, omdat ze van vroeg tot laat moeten werken om hun hoge hypotheek af te lossen. Ook hielden ze zich onvoldoende aan de specifieke gedragscodes die van oudsher in de tuindorpen gelden.

'Eerder kwamen ze zich gewoon netjes voorstellen als er nieuwe mensen kwamen en dat gebeurt niet meer. En je kreeg ook voorrang voor een woning als je van het Dorp kwam, dat is nu niet meer zo', aldus een deelnemer aan een ander groepsinterview in Tuindorp Buiksloot. ${ }^{17}$

Dit soort gevoelens zijn onder oorspronkelijke bewoners breed aanwezig en zijn van belang om de sfeer en context te begrijpen waarbinnen de verbindende projecten die wij bestudeerd hebben plaatsvonden.

Het gevoel van vervreemding dat oorspronkelijke bewoners ervaren, wordt sterk gekoppeld aan gentrificatie en de komst van 'yuppen' of 'nieuwe Noorderlingen' in de buurt. Maar zoals een van de citaten hierboven laat zien, zijn gevoelens van vervreemding al langer aanwezig door de komst van mensen van 'buitenlandse' komaf, die volgens de oorspronkelijke bewoners profiteren van allerlei publieke voorzieningen terwijl zij zelf in armoede leven (zie ook Ypeij e.a., 2002, 79-85). In deze bijdrage richten wij ons met name op thuisgevoelens in de wijk of het gebrek daaraan in relatie tot gentrificatie, omdat dit thema domineerde in de interviews en omdat de buurtactiviteiten die wij bestudeerden veelal gekoppeld waren aan het pro-gentrificatiebeleid van de gemeente en de woningbouwcorporaties. Bovendien hebben verschillende buurten in Oud-Noord nog altijd een overwegend 'autochtoon' karakter en is de instroom van bewoners met een migratieach- 
tergrond relatief beperkt (Welschen, 2014; zie ook Ypeij e.a., 2002, 39). Wij realiseren ons echter dat de huidige ontwikkelingen die tot gevoelens van uitsluiting en vervreemding leiden onderdeel zijn van lange termijn processen en van allerlei vormen van diversiteit; we zullen hier in het gedeelte over sociale ruimtes op terugkomen.

Zoals we in de inleiding al suggereerden, leidt gentrificatie of de komst van meer kapitaalkrachtige bewoners tot een 'remake' van de buurt, die van imago verandert (Zukin, 2010) en voorzieningen krijgt die primair de nieuwe middenklassebewoners bedienen, zoals hippe koffiebars, speciaalzaken en yogascholen (Hochstenbach e.a., 2015, 757; Hoekstra e.a., 2018). De aanpassingen van allerlei voorzieningen aan de nieuwe bewoners en 'yuppen' leidt bij sommige oorspronkelijke bewoners tot een gevoel van vervreemding en verwijdering van hun alledaagse leefomgeving. Shaw en Hagemans (2015) laten zien dat ondanks dat oorspronkelijke bewoners hun huizen niet hoeven te verlaten, de verandering in voorzieningen door gentrificiatie wél leidt tot gevoelens van verdringing door het verlies van ontmoetingsplekken in de buurt. Pinkster (2016) suggereert dat dit extra hard aankomt in gevallen waar oud-bewoners een uitermate sterk gevoel van buurtidentiteit hebben ontwikkeld (zoals in Betondorp en in de Noordse tuindorpen; Welschen, 2014). In het volgende laten wij zien dat niet alleen veranderende voorzieningen maar ook het aanbod van nieuwe activiteiten kan bijdragen aan vervreemding en uitsluiting.

\section{Verbindende projecten}

Beleidsmakers en welzijnswerkers in Amsterdam-Noord hebben de afgelopen jaren geprobeerd de gevoelens van vervreemding onder oorspronkelijke bewoners te verminderen door bij te dragen aan verbindingen tussen verschillende bewoners (Stadsdeel Amsterdam Noord , 2019). Nieuwe buurtbewoners met een middenklasse achtergrond, onder wie creatieve professionals als muzikanten en kunstenaars, werden sinds 2005 actief benaderd door de gemeente, welzijnsinstellingen en woningbouwcorporaties om door 'placemaking'-projecten en bewonersinitiatieven sociale cohesie te bevorderen en een dynamische sfeer in de buurten te creëren. Ook kwamen er ruimtes beschikbaar, waaronder voormalige buurthuizen die geen subsidie meer kregen, waar kunstenaars en andere creatievelingen in ruil voor een lage of geen huur iets terug moesten doen voor de buurt. Een belangrijk doel van de projecten - van creatieve workshops en theater- en muziekvoorstellingen tot activiteiten voor kinderen en buurtmaaltijden - was volgens de initiators of begeleiders ${ }^{18}$ om de verbinding en ontmoeting tussen buurtbewoners te vergroten, en de omgang met diversiteit. Bij sommige projecten werd ook de educatieve waarde benadrukt (vergelijk Van Ankeren e.a., 2010, 13). Buurtprojecten en bewonersinitiatieven werden gesubsidieerd als expliciet werd benoemd dat het doel was om 'oude' en 'nieuwe' bewoners te verbinden. ${ }^{19}$ In deze projecten werd regelmatig een omschrijving gegeven van 'oude Noorderlingen' en 'nieuwe Noordelingen', om op basis van die culturele typeringen mensen kennis te laten maken met een andere cultuur en levensstijl. De 'oude Noorderlingen' 
werden bijvoorbeeld getypeerd als 'volks', 'authentiek', 'afkomstig uit de Jordaan', 'overlevers' en 'rap van de tongriem gesneden'. De 'nieuwe Noorderlingen' werden omschreven als 'pioniers', 'creatieve professionals' die 'bewust in het leven staan', 'jonge kopers en gezinnen die een betaalbaar huis zoeken'. 20

Verschillende buurtinitiatieven en projecten richtten zich op kunst en cultuur. Als onderdeel van de beleidsfocus op de creatieve stad (Peck, 2012) wordt cultuur als potentiële motor gezien voor innovatie en vooruitgang (Florida, 2002; Landry, 2000). In dit kader wordt cultuur gepresenteerd als een middel om sociaal kapitaal (Putnam, 2000) te genereren, en de ontwikkeling van vaardigheden die nodig zijn voor maatschappelijke emancipatie (Ministerie VROM, 2007; zie ook Miles \& Paddinson, 2005). Cultuur wordt ingezet om sociale problemen als werkloosheid en armoede in stadsbuurten aan te pakken (zie bijvoorbeeld Grimm e.a., 2013; Tonkens \& De Wilde, 2013). Bovendien wordt cultuur gezien als een cruciaal middel om een inclusieve stad te creëren door een rijke culturele geschiedenis te benadrukken en een gedeelde identiteit te definiëren (Gemeente Amsterdam, 2003 in Peck, 2012, 463).

\section{Verbindende projecten die leiden tot vervreemding: een voorbeeld}

We presenteren hier één voorbeeld van een buurtproject gericht op verbinding in en met de buurt om een micro-kwalitatief perspectief te bieden op de dynamiek van sociale in- en uitsluiting die wij op verschillende momenten in ons veldwerk waarnamen. Het initiatief werd gesubsidieerd door een fonds voor cultuur en ondersteund door een woningcorporatie. Het bestond uit een reeks opeenvolgende workshops met bewoners geleid door een creatieve professional, de initiatiefneemster, gericht op het gezamenlijk ontwerpen van een eetbaar kunstwerk dat de buurt zou representeren. De initiatiefneemster stelde zich tot doel om een participatief proces van samen kunst maken te faciliteren, geïnspireerd op de verhalen en beelden van buurtbewoners. Ze wijdde een van de workshops aan het thema koken met een beperkt budget. De kunstenares had een lijst met creatieve opties gemaakt om te overleven met een klein budget, die ze presenteerde tijdens de workshop in een buurthuis.

Een van de deelneemsters, Wilma (55 jaar), vertelde hoe ze vaak geen geld had toen haar kinderen opgroeiden en dan oud brood verzamelde om flensjes van te bakken. De kunstenares reageerde enthousiast en nam dit voorbeeld op in haar lijst. Tijdens de volgende workshop bracht ze oud brood mee om samen met de deelnemers flensjes te bakken. Een week later sprak Van de Kamp Wilma op straat en Wilma merkte op dat ze het vreemd vond dat de kunstenares zo aangenaam verrast was door het idee om flensjes te maken; voor Wilma en andere buurtbewoners was het een vanzelfsprekende manier om te overleven. Wilma vroeg zich af: 'Krijgt zij subsidie om ons te leren hoe we met weinig geld eten kunnen maken? Begrijp jij dat nou?'21 Desondanks assisteerde Wilma de kunstenares vrijwillig en was ze trots op het eindproduct: een brood dat door de ingrediënten, vorm en decoratie aspecten van de buurt symboliseerde. Het werd tijdens een buurtfestival verkocht. Wilma nodigde haar kinderen en kleinkinderen uit om 
hen te trakteren op dit speciale broodje. Wilma leefde van een wekelijkse toelage van ongeveer $€ 50$ en was teleurgesteld toen ze op het festival zag dat de broodjes voor elk $€ 3$ werden verkocht en haar budget niet toereikend was. Later bleek dat ze korting had kunnen krijgen, maar het leed was al geschied.

Een belangrijk knelpunt in de samenwerking tussen bewoners en initiators met verschillende achtergronden en sociaaleconomische posities is dat de onderlinge verhouding per definitie ongelijk is (Vermeij \& Kullberg, 2015, 22). Dit is duidelijk zichtbaar in het beschreven project, waarbij de kunstenares met goede bedoelingen haar eigen benadering van armoede representeert, die schuurt met de ervaringen van de bewoners die armoede aan den lijve ondervinden. Het project, dat bedoeld was te verbinden en zo bij te dragen aan het bridging kapitaal van bewoners, heeft als effect dat de oorspronkelijke bewoners zich door hun ongelijke positie binnen het project buitengesloten voelen in hun eigen buurt.

\section{De praktijk van verbinding is weerbarstig}

Zoals gezegd, is één verwacht positief effect van het sociaal mengen in buurten dat er een emancipatoir effect op oorspronkelijke bewoners uitgaat van de instroom van hoger opgeleide bewoners, die als rolmodellen zouden fungeren (Van Bochove, Tonkens \& Verplanke, 2014). Het gaat hier om een vorm van mengen van bewoners met verschillende sociaaleconomische achtergronden met het oog op sociale mobiliteit. Dit is conform de gedachte van Granovetter (1973) dat zogenaamde 'weak ties', zwakke verbanden, soms bijzonder krachtig zijn in het openstellen van nieuwe mogelijkheden. Een tweede verwacht effect gaat om het vergroten van sympathie en begrip voor elkaar. Volgens Van Bochove (in Van Bochove e.a., 2014) proberen beleidsmakers vooral dat laatste in hun pogingen om verschillen te overbruggen tussen mensen met verschillende sociaaleconomische en etnisch-culturele achtergronden.

Hoe invloedrijk het idee van bridging kapitaal ook is als beleidsideaal, de praktijk is een stuk weerbarstiger (zie voor een recente discussie Kleinhans e.a., 2019). Het verbinden van verschillende groepen in wijken is niet eenvoudig. Onderzoek naar gentrificatie laat zien dat sociale cohesie niet toeneemt na een instroom van nieuwe bewoners met hogere inkomens, en dat oorspronkelijke bewoners met een lager inkomen zich niet aan de nieuwe bewoners 'optrekken' (bijvoorbeeld Blokland, 2001; Miltenburg, 2017; Van Ham e.a., 2012). Verhoudingen tussen 'oude' en 'nieuwe' bewoners zijn vaak oppervlakkig en in het ergste geval vijandig (Lees, 2008, 2456; zie ook Wekker, 2017).

\section{Activiteit in eigen kring: het belang van de bingo}

Wilma, die meedeed aan het kunstproject, probeerde zelf ook een bewonersinitiatief op te zetten met subsidie van de gemeente. Zij wilde graag bingoavonden organiseren omdat die volgens haar in een behoefte voorzagen bij de oorspronkelijke bewoners. Ze slaagde er niet in om subsidie te krijgen, omdat haar activiteit te eenzijdig zou zijn en geen diverse groep mensen zou aantrekken; met andere 
woorden, haar plan was te sterk gericht op het bevorderen van bonding kapitaal. Bovendien werd haar duidelijk gemaakt dat het niet de bedoeling was dat ze geld zou verdienen aan de activiteit. Toen Van de Kamp hier navraag naar deed, legde de betrokken welzijnsprofessional uit dat ambtenaren en andere professionals regelmatig het idee hadden dat de 'oud-Noorderlingen' probeerden om een zakcentje te verdienen aan de activiteiten. ${ }^{22}$ Wilma merkte op dat de nieuwkomers geld verdienen met de workshops die ze geven. Volgens de betrokken ambtenaar lag dat anders, omdat nieuwkomers als creatieve professionals werden ingehuurd, ook al zijn ze in allerlei gevallen ook bewoner. Wilma gaf tijdens onze gesprekken ook aan dat ze vermoedde dat andere oorspronkelijke bewoners, die via de denktank Bewonersinitiatieven mochten meebeslissen over de financiering van initiatieven, negatief geadviseerd zouden hebben over haar plan omdat ze jaloers zijn of haar niet mogen.

Wilma besloot om zonder subsidie bingoavonden te organiseren door entreegeld te vragen; ze kon de kosten relatief laag houden omdat ze toestemming kreeg van de woningbouwcorporatie om het buurthuis gratis te gebruiken. Haar activiteit werd druk bezocht en bewoners vroegen haar om niet maandelijks maar wekelijks avonden te organiseren. Mede door dit succes lukte het haar om in een later stadium wél subsidie te krijgen.

De deelnemers aan de bingoavonden maakten duidelijk dat in hun stressvolle bestaan van ziekte en schulden deze avonden lichtpuntjes waren: 'je vergeet even alle zorgen', 'we kunnen lekker met elkaar ouwehoeren' en 'je wint altijd wel iets'. ${ }^{23}$ In verschillende gesprekken benadrukten de bewoners dat ze ergens naartoe konden in de buurt: 'het is vlakbij', 'als er thuis wat is, kan ik zo weer terug', 'het kost niet zoveel', dat laatste in verhouding tot allerlei nieuwe activiteiten en restaurants in de buurt. Ze gaven aan al die andere activiteiten 'van de kopers' prima te vinden 'als ik er maar niet heen hoef'; ze vonden de muziek, de aankleding en het eten maar niks. De nieuwe jonge mensen en kinderen in de buurt werden op zichzelf dus niet als probleem gezien, als 'ze maar niet alles van ons afpakken'. Zolang ze toegang kunnen houden tot hun eigen voorzieningen zoals bingoen dansavonden in de buurthuizen en tot cafés waar de koffie nog $€ 1$ is, zien zij geen problemen: 'heb ieder z'n eigen pleziertje'. Wel gaven ze blijk van gevoelens van ongelijke behandeling, bijvoorbeeld omdat kopers volgens hen makkelijker subsidie krijgen dan zij. Zodra de gesprekken gingen over buurthuizen die dicht moesten en over nieuwkomers die naar hun idee wel van alles voor elkaar kregen, namen de negatieve uitlatingen over nieuwe bewoners toe.

\section{De waarde van bonding kapitaal}

Als het gaat over sociale cohesie in wijken die door veranderingen onder druk staat, dan gaat het onder meer om de afname van bonding kapitaal tussen oorspronkelijke bewoners. Veranderingen in de gentrificerende wijken leiden tot gevoelens van vervreemding bij oorspronkelijke bewoners van hun dagelijkse leefomgeving, die mensen ertoe kunnen brengen om zich uiteindelijk terug te trekken uit het buurtleven. Verschillende auteurs wijzen erop dat overeenkomsten 
tussen bewoners de onderlinge binding, het vertrouwen en de inzetbaarheid ten goede komen (Vermeij \& Kullberg, 2015, 24). In Oud-Noord zien we dat bewoners van het eerste uur zich sterk verbonden voelden met de wijk en met elkaar, maar dat die verbondenheid onder druk staat. Er is een afname van het gemeenschapsgevoel onder 'gelijkgestemden', omdat er simpelweg minder 'gelijken' wonen in de buurt en er zijn spanningen tussen verschillende bewonersgroepen. Dat kan worden ervaren als een erosie van de sociale ondersteuningsstructuur, die juist voor groepen met een lagere sociaaleconomische positie zo van belang is.

Woolcock $(2001,72)$ schrijft in relatie tot kwetsbare groepen, in het bijzonder armeren, dat deze vaak leunen op een hechte en intensieve 'voorraad' van bonding social capital in hun dagelijkse 'overleven'. Hun toegang tot bridging sociaal kapitaal is veel beperkter. De sterke sociale relaties en normen van wederkerigheid die voortkomen uit bonding social kapitaal helpen mensen om te gaan met de eisen van het dagelijks leven en bieden emotionele en expressieve ondersteuning (Dominiquez \& Arford, 2010, 117; Terrion, 2006, 158). Juist uit deze relaties halen mensen in de eerste plaats hun sociale ondersteuning. Dit laatste werd bevestigd tijdens ons onderzoek, en de bingo's zijn daar een voorbeeld van (zie ook Ypeij e.a., 2002). Ook uit de groepsinterviews van Welschen (2014) bleek de belangrijke ondersteunende functie van activiteiten in eigen kring voor kwetsbare bewoners. De dreigende sluiting van het buurtcentrum en het wegvallen van activiteiten als de buurtmaaltijd werden in direct verband gebracht met het welzijn van kwetsbare ouderen in de buurt, en van oud-bewoners die nu in verpleeghuizen wonen:

'[We moeten] behouden wat er is, koken voor de ouderen, dat ze hier kunnen eten. Veel eenzame ouderen en mensen die op de kleintjes moeten letten. Op maandagavond kunnen ze hier eten voor een klein bedrag. (...) Ze zijn blij dat ze in hun eigen buurtje kunnen komen. Hun kinderen zijn hier opgegroeid. Die mensen zijn naar bejaardentehuizen gegaan, aanleunwoningen, en worden naar [het Buurtcentrum] gebracht met het busje. Het voelt alsof ze uit eten zijn. Hier komen ze hun vriendinnen weer tegen. En dat is geweldig om te zien!'24

De veranderingen in de buurt, die het gevolg zijn van instroom van nieuwe bewoners in combinatie met hervormingen in het welzijnsbeleid, geven veel oud-bewoners het gevoel dat hen iets wordt afgenomen. In het onderzoek van Welschen (2014) kwam een breed gevoel van verlies naar voren, en van nostalgie naar hoe het in de buurt was voor de veranderingen. Zoals in dit citaat:

'Op woensdagavond heeft [de jongerenwerker] hier een kookclub. Iedereen kan aanschuiven. Jongens die op straat hangen en anders rottigheid uithalen, maar ook oudere mensen. Als dit moet sluiten, dan denk ik: je pakt wel alles weg he!'25

Niet voor niets stellen Vermeij en Kullberg (2015, 24): 'Het zou mooi zijn als er meer stedelijke buurten komen waarin ook minder kapitaalkrachtige stedelingen 
naar eigen inzicht vorm kunnen geven aan een lokale samenleving die eigen voelt.' 26

Tegelijkertijd wijzen onderzoekers ook op de keerzijden van te sterke 'bonding ties'. Bonding sociaal kapitaal kan leiden tot het stellen van hoge eisen aan de groepsleden, die zich beknot kunnen voelen in hun vrijheid (Domínguez \& Arford, 2010). Het kan bovendien leiden tot mechanismes van uitsluiting bijvoorbeeld doordat een beperkte groep zich een buurthuis grotendeels 'toe-eigent' (Van Bochove, 2014) of deelnemers uitsluit. Zo voelde Wilma zich buitengesloten doordat niet alleen welzijnsprofessionals maar ook andere oorspronkelijke bewoners haar bingo-initiatief afkeurden. In Tuindorp Buiksloot bleek in interviews dat oorspronkelijke bewoners zich niet altijd even welkom voelden bij activiteiten of op plaatsen waar andere oorspronkelijke bewoners een prominente rol hadden. Een deelneemster aan een groepsinterview beschrijft hoe buurtvoorzieningen in haar ogen door een selecte groep bewoners worden toegeëigend:

'Bij de speeltuin zat altijd de familie [X], en daardoor werden nieuwe vrijwilligers tegengehouden. Er kwam toch maar een afgebakende groep, dat zie je hier [in het buurtcentrum] nu ook. ${ }^{27}$

Van Bochove $(2014,88)$ stelt dat nu het beheer van publieke voorzieningen steeds meer een aangelegenheid wordt van actieve burgers zoals bewoners, het ideaal van bridging steeds verder onder druk komt te staan. Uit haar studie blijkt dat de dagelijkse praktijk in buurthuizen (en speeltuinen) vooral uit bonding bestaat. Pragmatische professionals die in dit soort voorzieningen werken, hebben volgens haar het ideaal van bridging al losgelaten en zetten er vooral op in dat de voorziening publiek toegankelijk blijft voor iedereen. Dit brengt ons bij de vraag wat de rol van ontmoetingsplekken is als het gaat om sociale cohesie in buurten.

\section{Het belang van publieke ontmoetingsplaatsen}

In het voorgaande hebben we laten zien dat activiteiten gericht op het verbinden van verschillende groepen en mensen vaak te ambitieus zijn. Bovendien stellen we dat het van belang is tegemoet te komen aan de reële zorgen van oorspronkelijke bewoners over toenemende vervreemding en het wegvallen van sociale ondersteuningsstructuren. Dat kan juist door hen ertoe in staat te stellen om hun bonding sociaal kapitaal te versterken. Tegelijkertijd kan een te grote nadruk op bonding kapitaal ook tot vormen van uitsluiting leiden. Zowel een eenzijdige inzet op bonding kapitaal als een sterke focus op bridging kapitaal heeft daarom zijn beperkingen. De relevante vraag voor beleid is dan ook op welke manier vervreemding onder oorspronkelijke bewoners kan worden tegengegaan, en hoe tegelijk een mate van 'inclusiviteit' kan worden bereikt.

Wij denken dat het antwoord te vinden is door te kijken naar de verschillende functies die ontmoetingsplaatsen en sociale ruimtes hebben. 
Blokland (2017, 36-41) wijst erop dat de studies van Putnam en anderen over sociale cohesie niet alleen gaan over de contacten en netwerken die mensen hebben, maar juist ook over institutionele verbanden en ruimtes die mensen de mogelijkheden bieden om anderen te ontmoeten. De werkelijk interessante vraag die Putnam daarmee aan de orde stelt, is volgens Blokland: waarom bieden bepaalde sociale settings een vruchtbare bodem voor sociaal kapitaal en andere niet? Volgens Blokland zijn sterke en zwakke banden tussen mensen, of bonding en bridging kapitaal, niet de doorslaggevende factor als het gaat om het thuisgevoel in de stad (belonging); van groter belang zijn sociale ruimtes - bijvoorbeeld straat, supermarkt, voetbalveld en buurthuis - en hoe mensen daar 'gemeenschap doen' (doing community). Praktijken en activiteiten geven vorm aan verschillende niveaus van cohesie en belonging zonder dat mensen noodzakelijkerwijs sterke of zwakke relaties met elkaar hebben of aangaan.

Een concreet voorbeeld hiervan is het door Blokland (2009) geïntroduceerde concept 'publieke familiariteit' dat tot stand komt door regelmatige, terloopse ontmoetingen tussen 'vreemden' in de publieke ruimte. Het komt tot stand, aldus Kleinhans en Bolt $(2010,13)$, in contacten met buren over de schutting, op het schoolplein of bij de koffieochtend voor ouderen. Het herkend worden en elkaar groeten is al voldoende. Door deze korte interacties krijgen bewoners voldoende informatie over de ander om deze sociaal te kunnen plaatsen. Daarmee stijgen het onderling vertrouwen en het gevoel van sociale veiligheid. Mensen voelen zich gekender en durven elkaar aan te spreken. Uiteindelijk, zo toont onderzoek aan, worden wijken daar leefbaarder van (zie onder andere Blokland, 2008a; Duyvendak \& Wekker, 2003; Snel, Hoogmoed \& Odé, 2015). Publieke familiariteit heeft een positieve invloed op het gevoel van thuishoren in de wijk zonder dat mensen elkaar echt goed hoeven te kennen. Hoekstra en Dahlvik (2018) stellen dat bewoners vaak niet per se op zoek zijn naar intensieve vormen van contact en hechte verbanden, maar dat zij ook waarde hechten aan deze meer oppervlakkige vormen van contact. Uit ons eigen onderzoek in Oud-Noord blijkt ook dat bewoners een behoefte hebben aan een mate van publieke familiariteit, die in de veranderende wijk overigens niet altijd gemakkelijk tot stand komt:

'Vroeger had je ook geen hekken tussen tuinen, nu hebben mensen een schutting. Vroeger had je een gezellig hegje en een kolenkit en dan kletste je gezellig met elkaar in de tuin en dat gebeurt niet meer. ${ }^{28}$

Publieke familiariteit kan gestalte krijgen in allerlei ontmoetingsplaatsen in de wijk, zoals pleinen, speeltuinen en buurthuizen. De manier waarop sociale ruimtes zijn vormgegeven, en wat er te doen en te zien is, maakt de ongedwongen uitwisseling en ontmoeting tussen buurtbewoners mogelijk (Blokland, 2008b; vergelijk Fischer, 1982; Van der Zwaard, 2010). Daarom is het van belang dat deze ruimtes herkenningspunten bieden voor verschillende mensen (Hall \& Datta, 2010). Engbersen en Snel (2015) brengen publieke ontmoetingsruimtes in verband met publiek kapitaal. Publiek kapitaal is van belang om andere vormen van kapitaal te laten floreren. Laagdrempelige voorzieningen die bewoners allerlei 
mogelijkheden bieden - informatie, zorg, ontmoeting, creativiteit - zijn voorbeelden van publiek kapitaal.

\section{Het buurthuis als ruimte voor publieke familiariteit}

Tijdens ons onderzoek hebben wij participerende observaties en interviews gedaan in verschillende buurthuizen. Sommige buurthuizen waren voornamelijk gericht op een bepaalde groep oorspronkelijke bewoners of juist alleen op nieuwe bewoners, in het geval van enkele broedplaatsen waar niet alle bewoners zich welkom of thuis voelden. Echter, we hebben ook voorbeelden gezien van buurthuizen waar verschillende groepen bewoners in de wijk gebruik van maakten. In het geval van één buurthuis spraken zowel 'nieuwe' als 'oude' Noorderlingen erover als een fijne plek in de wijk omdat ze er gemakkelijk naartoe konden met hun (klein)kinderen vanwege de aangrenzende speeltuin en de buitenschoolse opvang in een deel van het gebouw. Daarnaast komen ouders met verschillende achtergronden elkaar tegen in de judozaal, waar verschillende kinderen in de wijk judoles volgen. Bovendien komen verschillende oorspronkelijke bewoners er voor hun bingoavonden en wordt het buurthuis verhuurd voor feestjes en gebruikt als stemlokaal tijdens verkiezingen. Ook vinden er zo nu en dan bewonersavonden met de gemeente plaats. De mix van locatie - langs een veelgebruikte route -, verschillende functies, betrokkenheid van diverse stakeholders (verenigingen, bewonersgroepen, gemeente en organisaties) en daarbij horende financiële structuren lijkt het publieke kapitaal van dit buurthuis te faciliteren en te versterken (zie ook Blokland, 2008b; De Kreek e.a., 2018).

De publieke familiariteit die in ontmoetingsplaatsen als deze ontstaat, vindt plaats in een context van diversiteit (Duyvendak, 2011). Een aspect van deze diversiteit is dat bewoners op verschillende manieren verbonden zijn met de plek en buurt waar zij wonen (Hall \& Datta, 2010). In gentrificerende buurten zoeken kapitaalkrachtige bewoners bijvoorbeeld naar 'hippe' restaurants en hotspots ${ }^{29}$ (vergelijk Savage, Bagnall \& Longhurst, 2005), terwijl oorspronkelijke bewoners herinneringen aan vroeger hebben bij verschillende plekken in de buurten die ze graag willen behouden. In het algemeen blijkt dat mensen zich thuis voelen in een buurt als er punten van (h)erkenning zijn door het aanbod van winkels en culturele activiteiten, de esthetiek van de openbare ruimte en de links met het verleden (voor een recente studie zie Van der Wilk, 2016). Het is in dit kader dat Blokland (2017, 131-136) oproept om niet alleen te kijken naar de relaties die mensen onderling hebben en naar bridging en bonding kapitaal, maar aandacht te hebben voor het publieke kapitaal dat ruimtes kunnen belichamen.

Bovendien lijkt het ontmoeten van verschillende mensen vanzelfsprekender te worden als verbinding geen direct doel is. Als de judo in de sporthal is waar de hangjongeren voetballen, als de voorscholen en de kinderopvang in dezelfde speelzalen zitten en zowel monoculturele als multiculturele activiteiten in hetzelfde buurthuis plaatsvinden, dan komen mensen elkaar vanzelf tegen in plaats van dat er van bovenaf op contact wordt aangestuurd. Dit biedt geen garanties op intensiever contact, maar wel routes voor potentieel sporadisch contact (Blok- 
land, 2008b). Dat kan volstaan, omdat sociale cohesie niet noodzakelijkerwijs gaat om intensief contact tussen buurtbewoners, maar om het idee of gevoel dat je met anderen te maken hebt, en zij met jou, zonder specifieke doelen en bedoelingen.

Een publieke ontmoetingsplek die sporadisch contact tussen verschillende bewoners mogelijk maakt en tegelijkertijd ruimte biedt voor een bepaalde mate van bonding door activiteiten binnen een eigen kring, lijkt daarom een goede manier om cohesie en thuis voelen in de buurt voor iedereen te bevorderen.

\section{Tot besluit}

Allerlei onderzoek laat zien dat verschillende bevolkingsgroepen in stadsbuurten weinig met elkaar optrekken en dat activiteiten gericht op het verbinden van verschillende gemeenschappen te ambitieus zijn (bijvoorbeeld Veldboer \& Duyvendak, 2001; Tonkens \& De Wilde, 2013; Wekker, 2017). Dit geldt ook voor de gentrificerende tuindorpen in Amsterdam-Noord. Toch blijft het ideaal van mengen op allerlei verschillende manieren centraal staan in stedelijk beleid (Uyterlinde \& Engbersen, 2018; Kleinhans e.a., 2019), zoals ook in het speerpunt 'de verbonden stad' van het huidige Amsterdamse stadsbestuur. Als het gaat om sociale cohesie, worden met name initiatieven gesubsidieerd die gericht zijn op het mengen van verschillende groepen. Bewoners die activiteiten organiseren in 'eigen kring' kunnen op weinig tot geen subsidie rekenen (Veldboer e.a., 2007, 20; zie ook Van Bochove, 2014, 87). Ons betoog is dat juist voor kwetsbare bewoners, bewoners die moeilijk mee kunnen komen in de veranderde wijk en samenleving of bewoners die zich niet meer thuis voelen in hun wijk, bonding met gelijken van waarde kan zijn. Dit lijkt des te meer het geval als deze bewoners een sterk gevoel van buurtidentiteit hebben ontwikkeld, zoals in de Noordse tuindorpen (zie ook Pinkster, 2016).

De ervaringen van Wilma zijn hier een goed voorbeeld van. Ondanks dat zij en andere oud-bewoners deelnamen aan 'verbindende activiteiten', leidde dit regelmatig tot miscommunicatie, onbegrip en wantrouwen tussen de deelnemers met verschillende achtergronden. Tegelijk had Wilma net als andere oud-bewoners moeite om subsidie te krijgen voor het draaiende houden van kaartclubs en het organiseren van bingo's. Terwijl de waardering voor en continuïteit van de laatstgenoemde activiteiten in de buurt juist bijdragen aan het tegengaan van vervreemding. Bewoners ervaren hierdoor dat er plek voor hen is in de buurt, waar ze worden gezien door anderen die hun historie, levensstijl en problemen herkennen. Het samenkomen met gelijken draagt in deze situatie bij aan onderling vertrouwen en zorgt ervoor dat mensen zich niet helemaal terugtrekken en mogelijk vereenzamen. In de context van een 'verbonden stad' is het van belang ervoor te zorgen dat oorspronkelijke bewoners zich zeker voelen over hun eigen plek en toekomst in de wijk. Daarna ontstaat er mogelijk ruimte voor overbruggende contacten.

Echter, zoals besproken, kunnen te sterke vormen van bonding kapitaal leiden tot allerlei vormen van uitsluiting. Daarom lijkt het dat beleidsmakers het beste kun- 
nen inzetten op een combinatie van verschillende gradaties van bonding en bridging initiatieven. Mensen moeten hun hechte banden in eigen kring kunnen versterken, maar tegelijkertijd een bepaalde lichte mate van vertrouwdheid ontwikkelen met mensen die verder van hen afstaan om niet alsnog te vervreemden van andere groepen in de buurt.

Het streven naar publieke familiariteit lijkt hierin een uitweg te bieden (Blokland, 2017). Een voorbeeld is het beschreven buurthuis of de locatie waar Wilma haar bingoavonden houdt, waar ook activiteiten als yoga plaatsvinden, waardoor verschillende mensen elkaar even kunnen treffen en zien. Het gaat hier niet zozeer om het overbruggen van verschillen, maar om het garanderen dat verschillende groepen elkaar in ieder geval een plek gunnen (Duyvendak, 2011; Van Bochove, 2014). Op deze manier voorzien geslaagde publieke ontmoetingsplaatsen in twee verschillende aspecten van sociale cohesie. Enerzijds kunnen deze plekken de ongedwongen uitwisseling en ontmoeting tussen verschillende buurtbewoners mogelijk maken door de diversiteit aan wat er te doen en te zien is. Anderzijds kunnen dezelfde sociale en publieke ruimtes de mogelijkheid bieden voor ontmoetingen en activiteiten in eigen kring die met name voor oorspronkelijke bewoners bijdragen aan meer vertrouwen over de eigen plek in de wijk. Vanuit een eigen veilige positie is het gemakkelijker de hand te reiken naar 'nieuwkomers', die ook zoeken naar herkenbare plekken in de wijk.

\section{Noten}

1 In beleidstermen duiden 'kwetsbare buurten' wijken aan die achterblijven op diverse indicatoren, zoals leefbaarheid, veiligheid en sociaaleconomische status (Dorigo, Leidelmeijer \& Zeelenberg, 2017). In Amsterdamse beleidsstukken worden ze op dit moment ook wel 'ontwikkelbuurten' genoemd en eerder 'Vogelaarwijken', 'aandachtswijken', 'krachtwijken' en 'focuswijken'.

2 Volgens verschillende onderzoekers is deze traditie aan het verdwijnen (Uitermark, 2009; Savini e.a., 2016; Van Gent \& Boterman, 2019). Lange tijd waren sociale huurwoningen voor een brede middenklasse bedoeld, terwijl vandaag de dag een proces van 'residualisering' optreedt: door de krappe Amsterdamse woningmarkt worden sociale huurwoningen in steeds sterkere mate bewoond door huishoudens in de lagere/laagste inkomensgroepen (Van Kempen \& Priemus, 2002). Bovendien is er sprake van ruimtelijke marginalisering doordat lage inkomens in toenemende mate geconcentreerd raken in buurten met veel sociale huur (Van Gent e.a., 2014; zie ook Welschen en Veldboer in dit themanummer).

3 Ook zogenoemde 'gentrifiers' wonen regelmatig in sociale huurwoningen; qua levensstijl en opleiding worden zij als 'gentrifiers' of 'yuppen' (young urban professionals) gekwalificeerd, maar zij zijn niet noodzakelijkerwijs kapitaalkrachtig.

4 In dit artikel gebruiken we de term 'oorspronkelijke bewoners' voor de bewoners van het eerste uur en bewoners die langdurig in Noord wonen, alsook hun (klein)kinderen, die zichzelf regelmatig 'Noorderling' noemen en in beleidsstukken ook wel 'oud-Noorderlingen' worden genoemd. Wij merkten tijdens ons onderzoek dat deze termen voor beleidsmakers en nieuwe bewoners veelal samenvallen met sociaaleconomische posi- 
ties. Met de term 'oorspronkelijke bewoners' en 'oud-Noorderlingen' wordt meestal gerefereerd aan de voormalige arbeiders en aan bewoners die minder kapitaalkrachtig zijn.

5 Sociale cohesie wordt vaak als toverwoord gebruikt voor het oplossen van problemen in wijken. Tegelijk is het een subjectief begrip. Voor de een gaat het om intensief contact tussen buren, terwijl voor de ander kortstondige ontmoetingen voldoende zijn. Bovendien kan iemand zich thuis voelen in een wijk die als onveilig is bestempeld, omdat diegene de straatcodes kent en weet wie te vertrouwen is en wie niet (Blokland, 2008, 5-6). Wij hechten er daarom aan om in deze bijdrage zo veel mogelijk het perspectief van bewoners weer te geven.

6 Dit onderzoek is gefinancierd met een Veni-beurs van de Nederlandse Organisatie voor Wetenschappelijk Onderzoek.

7 De plannen worden steeds bijgestuurd, maar het is duidelijk dat van de ten minste 50.000 woningen die tussen 2018 en 2025 gebouwd moeten worden in Amsterdam, de meeste nieuwbouw plaatsvindt in Noord (Gemeente Amsterdam, 2016). Zoals de manager gebiedsontwikkeling Amsterdam-Noord zei: 'Je moet het zo zien, dat we 1/3 van de fysieke massa er in zo'n 10 jaar bij gaan zetten met z'n allen, in AmsterdamNoord, even voor het gevoel' (Pakhuis de Zwijger, 'Het Nieuwe Noord', 25 maart 2019). Zie ook Gemeente Amsterdam, 2017.

8 Dit protest was onder andere te zien en te horen tijdens een van de informatieavonden die de gemeente organiseerde over de plannen voor het Sixhavengebied op 22 februari 2018 (zie ook Bijholt, 2018).

9 Deze uitspraak kwam in meerdere interviews in de verschillende tuindorpen naar voren.

10 Groepsinterview Tuindorp Buiksloot, 2 mei 2013.

11 Interviews met bewoners uit Tuindorp Nieuwendam (18 november 2016) en Tuindorp Buiksloot (13 februari 2019). Het stigma dat deze bewoners ervaarden, had onder andere te maken met de geschiedenis van de sociale woningbouw aan het begin van de twintigste eeuw, die gepaard ging met een beschavingsoffensief om arbeidersgezinnen bepaalde maatstaven van netheid en fatsoen bij te brengen (De Regt, 1995; Steinmetz, 2016).

12 www.nul20.nl/dossiers/amsterdam-investeert-miljoenen-kwetsbare-buurten, geraadpleegd op 29 maart 2019.

13 Zie bijvoorbeeld de projectnota Hamerkwartier (Gemeente Amsterdam, 2018a), waarin de 'Ongedeelde Wijk' een van de centrale doelstellingen is. Inzet is dat bij de ontwikkeling van de nieuwe wijk omliggende buurten (IJplein, Vogelbuurt) meeprofiteren.

1416 mei 2013.

15 Idem.

16 Idem.

1727 mei 2013.

18 Dit waren in de praktijk ambtenaren, managers en gebiedsbeheerders van woningbouwcorporaties, welzijnswerkers, betrokken creatieve professionals en enkele bewoners.

19 Interview met een lid van de denktank Bewonersinitiatieven Volewijck, 6 februari 2017, en gesprekken met creatieve professionals in periode 2010-2017. 
20 Deze quotes komen uit allerlei flyers die de initiatiefnemers in de buurten en via sociale media verspreidden en die wij hebben verzameld als onderdeel van het onderzoek. Opvallend is dat eerdere nieuwkomers, zoals de gezinnen met een Marokkaanse en Turkse achtergrond, meestal niet benoemd werden in deze projecten.

21 December 2013.

22 Gesprekken met de betrokken professionals over deze casus vonden plaats in de periode februari tot april 2014.

23 De verschillende quotes in deze paragraaf komen uit gesprekken die gevoerd zijn tijdens verschillende bingo's in de Volewijck: 29 januari 2016, 18 maart 2016, 5 februari 2017 en 15 januari 2019.

24 Groepsinterview Tuindorp Buiksloot, 2 mei 2013.

25 Deelneemster groepsinterview Tuindorp Buiksloot, 30 mei 2013.

26 Zie ook Pinkster $(2017,88)$ voor een soortgelijk punt.

27 Groepsinterview Tuindorp Buiksloot, 16 mei 2013.

28 Groepsinterview Floradorp (Volewijck), 3 juni 2013.

29 Wij hebben in deze bijdrage geen ruimte om in te gaan op de thuisgevoelens in de buurt van nieuwere kapitaalkrachtige bewoners. Het is niet zo dat zij zich automatisch thuis voelen in de buurt vanwege hun sociaaleconomische positie. Wél ondervonden wij tijdens ons onderzoek dat de meeste nieuwkomers minder afhankelijk zijn van hun netwerk in de buurt in vergelijking met kwetsbare oorspronkelijk bewoners. Bovendien blijken met name de buurtnetwerken van kapitaalkrachtige nieuwe bewoners met kinderen zich te concentreren in en rond scholen en kinderopvang die populair zijn onder deze nieuwe bewoners. Zij gaven regelmatig aan (ook) geen interesse te hebben in verbindende activiteiten met oorspronkelijke bewoners.

\section{Literatuur}

Ankeren, M. van, Tonkens, E.H., \& Verhoeven, I. (2010). Bewonersinitiatieven in de krachtwijken van Amsterdam: een verkennende studie. Amsterdam: Hogeschool van Amsterdam/Universiteit van Amsterdam.

Avest, D. ter (2015). Betekenisvolle ontmoetingsplekken: Nieuwe strategieën en hernieuwde tactieken. Rotterdam: WMO werkplaats.

Bijholt, T. (2018). 'Developing in the spirit of North': a qualitative research on residents' place attachment and experiences with participating in the SASA area development (scriptie master Sociologie, Universiteit van Amsterdam).

Blokland, T. (2001). Middenklassers als middel. Het grotestedenbeleid en de betekenis van midden- en hogere inkomensgroepen voor grootstedelijk sociaal kapitaal. Beleid en Maatschappij, 28 (1): 42-53.

Blokland, T. (2008a). Oog voor elkaar: veiligheidsbeleving en sociale controle in de grote stad. Amsterdam University Press.

Blokland, T. (2008b). Ontmoeten doet er toe: een essay. Uitgave Vestia.

Blokland, T. (2009). Het belang van publieke familiariteit in de openbare ruimte. Beleid en Maatschappij, 36 (3): 183-191.

Blokland, T. (2017). Community as Urban Practice. Cambridge: Polity Press.

Bochove, M. van (2014). Ieder zijn eilandje. Bonding en bridging in buurthuizen en speeltuinen. In: M. van Bochove, E. Tonkens \& L. Verplanke (red.), Nieuwe verhoudingen tussen vrijwilligers en professionals in zorg en welzijn. Den Haag: Platform 31, 87. 
Bochove, M. van, Tonkens, E., \& Verplanke, L. (2014). Kunnen we dat (niet) aan vrijwilligers overlaten? Nieuwe verhoudingen tussen vrijwilligers en professionals in zorg en welzijn. Den Haag: Platform 31.

Bredewold, F., Duyvendak, J.W., Kampen, T., Tonkens, E., \& Jansen Verplanke, L. (2018). De verhuizing van de verzorgingsstaat. Hoe de overheid nabij komt. Amsterdam: Van Gennep.

Bridge, G., Butler, T., \& Lees, L. (red.) (2012). Mixed Communities: Gentrification by Stealth? University of Bristol/Polity Press.

Dercksen, A., \& Verplanke, L. (2005). Geschiedenis van de onmaatschappelijkheidsbestrijding in Nederland, 1914-1970. Amsterdam: Boom.

Domínguez, S., \& Arford, T. (2010). It is all about who you know: Social capital and health in low-income communities. Health Sociology Review, 19 (1): 114-129.

Donkers, J. (2007). Zo dicht bij Amsterdam: Opnieuw Herzien en Uitgebreid. Amsterdam: Atlas.

Dorigo, M., Leidelmeijer, K., \& Zeelenberg, S. (2017). Aandachtswijken op eigen kracht: ontwikkeling van de leefbaarheid in de (voormalige) aandachtswijken. Den Haag: Platform 31/RIGO Research en Advies.

Duyvendak, J.W. (2011). The Politics of Home. Belonging and Nostalgia in Western Europe and the United States. New York/Londen: Palgrave Macmillan.

Duyvendak, J.W., \& Wekker, F. (2003). Thuis in de openbare ruimte? Over vreemden, vrienden en het belang van amicaliteit. Den Haag: Platform 31.

Engbersen, G., Snel, E., \& Weltevrede, A. (2005). Sociale herovering in Amsterdam en Rotterdam: één verhaal over twee wijken (deel 8). Amsterdam University Press.

Engbersen, G., \& Snel, E. (2015, 11 juni). Als de burger het zelf moet doen, blijven arme buurten achter. NRC Handelsblad.

Fischer, C.S. (1982). To dwell among friends: Personal networks in town and city. University of Chicago Press.

Florida, R. (2002). The Rise of the Creative Class. And How It's Transforming Work, Leisure and Everyday Life. New York: Basic Books.

Gemeente Amsterdam (2012). Hervorming Stedelijke Vernieuwing. https:// assets.amsterdam.nl/publish/pages/476084/ notitie_hervorming_stedelijke_vernieuwing_5_juni.pdf, geraadpleegd op 4 april 2019.

Gemeente Amsterdam (2016). Koers 2025: Ruimte voor de Stad. Amsterdam: Gemeente Amsterdam.

Gemeente Amsterdam (2017). Gebiedsanalyse 2017/18, Oud Noord, Stadsdeel Noord. www.ois.amsterdam.nl/downloads/pdf/2017_gebiedsanalyse_18.pdf, geraadpleegd op 5 april 2019.

Gemeente Amsterdam (2018a). Hamerkwartier, Projectnota 2 oktober 2018. https:// assets.amsterdam.nl/publish/pages/

854818/03_projectnota_hamerkwartier_2_oktober_d_d_2018_web.pdf, geraadpleegd op 4 april 2019.

Gemeente Amsterdam (2018b). Een nieuwe lente en een nieuw geluid. Coalitieakkoord Groen Links/D66/PVDA/SP - mei 2018. www.amsterdam.nl/bestuur-organisatie/volg-beleid/ coalitieakkoord-2018/, geraadpleegd op 4 februari 2019.

Gent, W.P. van (2013). Neoliberalization, Housing Institutions and Variegated Gentrification: How the 'Third Wave' Broke in Amsterdam. International Journal of Urban and Regional Research, 37 (2): 503-522.

Gent, W. van, Musterd, S., Veldhuizen, E., Michon, L., \& Slot, J. (2014). De ongedeelde stad onder druk: de veranderende geografie van armoede in Amsterdam, 2004-2012. In: Armoede in Amsterdam: een stadsbrede aanpak van hardnekkige armoede, 47-57. 
Granovetter, M.S. (1973). The strength of weak ties. American Journal of Sociology, 78 (6): $1360-1380$.

Grimm, R., Fox, C., Baines, S., \& Albertson, K. (2013). Social innovation, An Answer to Contemporary Societal Challenges? Locating the Concept in Theory and Practice. Innovation: The European Journal of Social Science Research, 26 (4): 436-455.

Hall, S., \& Datta, A. (2010). The translocal street: Shop signs and local multi-culture along the Walworth Road, South London. City, Culture and Society, 1 (2): 69-77.

Ham, M. van, Manley, D., Bailey, N., Simpson, L., \& Maclennan, D. (red.) (2012). Neighbourhood Effects Research: New Perspectives. Dordrecht: Springer.

Hart, J.D., Knol, F., Maas-de Waal, C., \& Roes, T. (2002). Zekere banden. Sociale cohesie, leefbaarheid en veiligheid. Den Haag: Sociaal en Cultureel Planbureau.

Hochstenbach, C. (2017). State-led gentrification and the changing geography of marketoriented housing policies. Housing, Theory and Society, 34 (4): 399-419.

Hochstenbach, C., Musterd, S., \& Teernstra, A. (2015). Gentrification in Amsterdam: Assessing the importance of context. Population, Space and Place, 21 (8): 754-770.

Hoekstra, M.S., \& Dahlvik, J. (2018). Neighbourhood participation in super-diverse contexts: comparing Amsterdam and Vienna. Urban Research \& Practice, 11 (4): 441-459.

Hoekstra, M., Gent, W. van, \& Boterman, W. (2018). Kwartiermaken als symbolische politiek in overheidsgestuurde gentrificatie. Sociologos, 39 (3): 242-262.

Jong, E. de, Omlo, J., \& Kooiman, A. (2015). Nieuwe publieke ruimtes. Werkplaats Sociaal Domein Zuid-Holland.

Kamp, L. van de (2018). Stedelijke regeneratie in Amsterdam-Noord: over de politiek van erfgoed en creativiteit. Sociologos, 39 (3): 263-286.

Kamp, L. van de (2019). The heritagization of post-industrial re-development and social inclusion in Amsterdam. Journal of Urban Cultural Studies, 6 (2).

Kempen, R. van, \& Priemus, H. (2002). Revolution in social housing in the Netherlands: possible effects of new housing policies. Urban Studies, 39 (2): 237-253.

Kleinhans, R.J. \& Bolt, G. (2010). Vertrouwen houden in de buurt: Verval, opleving en collectieve zelfredzaamheid in stadsbuurten. Onderzoeksinstituut OTB/Universiteit Utrecht/ Nicis Institute.

Kleinhans, R., Veldboer, L., \& Duyvendak, J.W. (2019). Zeven vragen die elke protagonist van menging zou moeten stellen. Sociale Vraagstukken, 11 januari 2019.

Knol, F., Maas-de Waal, C., \& Roes, T. (2002). Zwakke Banden. Sociale cohesie, leefbaarheid en veiligheid. Den Haag: Sociaal en Cultureel Planbureau.

Kok, B. (2016). Oerknal aan het IJ, de geschiedenis van Amsterdam bezien vanuit Noord. Amsterdam: oliviamedia.

Kreek, M. de, Brinkhuijsen, A., Veldboer, L., \& Bos, E. (2018). Verbinding als motor van het sociale domein in Amsterdam Noord: een verkenning van informeel en formeel sociaal werk in de Molenwijk en Tuindorp Oostzaan. Amsterdam: Hogeschool van Amsterdam.

Kullberg, J. (2009). Interventies in de wijk. Waarom? Waar? En waarom daar. In: S. Musterd \& W. Ostendorf (red.), Problemen in wijken of probleemwijken. Assen: Van Gorcum.

Landry, C. (2000). The Creative City: A Toolkit for Urban Innovators. Londen: Earthscan.

Lees, L. (2008). Gentrification and social mixing: towards an inclusive urban renaissance? Urban Studies, 45 (12): 2449-2470.

Leydesdorff, S. (1990). 'Different from Those Across the Water': Interviews on the Construction of Collective Identity in Working-class Neighborhoods in the North of Amsterdam. In: R.L Grele (red.), International Annual of Oral History: Subjectivity and Multiculturalism. Westport: Greenwood, 43-55.

Marcuse, P. (1985). Gentrification, abandonment, and displacement: Connections, causes, and policy responses in New York City. Wash. UJ Urb. \& Contemp. L., 28: 195-240. 
Miles, S., \& Paddinson, R. (2005). Introduction: The Rise and Rise of Culture-led Urban Regeneration. Urban Studies, 42 (5/6): 833-839.

Milikowski, F. (2018). Van wie is de stad: de strijd om Amsterdam. Amsterdam: Atlas Contact.

Miltenburg, E. (2017). A Different Place to Different People. Conditional Neighborhood Effects on Residents' Socio-economic Status (doctoraatsthesis, Universiteit van Amsterdam).

Ministerie VROM (2007). Actieplan Krachtwijken. Van aandachtswijk naar prachtwijk. Den Haag: Ministerie VROM - Wonen, Werken en Integratie.

New York Times (2012, 12 april). Once Unfashionable, Noord District of Amsterdam Gains Cachet. New York Times.

Nul 20 (2017). Amsterdam investeert miljoenen in kwetsbare buurten. Nul 20, 93 (december). www.nul20.nl/dossiers/amsterdam-investeert-miljoenen-kwetsbare-buurten, geraadpleegd op 29 maart 2019.

Paton, K. (2014). Gentrification: A working-class perspective. New York: Routledge.

Peck, J. (2012). Recreative City: Amsterdam, Vehicular Ideas and the Adaptive Spaces of Creativity Policy. International Journal of Urban and Regional Research, 36 (3): 462-85.

Pinkster, F.M. (2016). Narratives of neighbourhood change and loss of belonging in an urban garden village. Social \& Cultural Geography, 17 (7): 871-891.

Pinkster, F.M. (2017). Those who feel left behind. In: V. Mamadouh \& A. van Wageningen (red.), Urban Europe. Fifty Tales of the City. Amsterdam University Press, 83-88.

Portes, A. (1998). Social capital: Its origins and applications in modern sociology. Annual review of sociology, 24 (1): 1-24.

Putnam, R.D. (2000). Bowling alone: America's declining social capital. In: Culture and politics. New York: Palgrave Macmillan, 223-234.

Regt, A. de (1995). Arbeidersgezinnen en beschavingsarbeid: ontwikkelingen in Nederland, 1870-1940: een historisch-sociologische studie. Amsterdam: Boom.

Savage, M., Bagnall, G., \& Longhurst, B. (2005). Globalization and Belonging. Londen: Sage.

Savini, F., Boterman, W.R., Gent, W.P. van, \& Majoor, S. (2016). Amsterdam in the 21st century: Geography, housing, spatial development and politics. Cities, 52: 103-113.

Savini, F., \& Dembski, S. (2016). Manufacturing the creative city: Symbols and politics of Amsterdam North. Cities, 55: 139-147.

Shaw, K. \& Hagemans, I. (2015). Gentrification Without Displacement and the Consequent Loss of Place: The Effects of Class Transition on Low-income Residents of Secure Housing in Gentrifying Areas. International Journal of Urban and Regional Research, 39: 323-341.

Snel, E., Hoogmoed, K., \& Odé, A. (2015). Actief burgerschap en leefbaarheid in twee Rotterdamse wijken. Bestuurswetenschappen, 69 (2): 71-84.

Stadsdeel Amsterdam Noord (2019)., Gebiedsagenda Oud Noord 2019. www.amsterdam.nl/ bestuur-organisatie/volg-beleid/gebiedsgericht/gebiedsplannen-2019/ gebiedsplannen-noord/oud-noord/, geraadpleegd op 4 april 2019.

Stadsdeel Amsterdam Noord (2018). Gebiedsplan Noord West 2018. http:// noord.amsterdamsamen.nl/wp-content/uploads/2017/12/

GP_NW_Gebiedsplan_2018_Noord_West_2_0.pdf, geraadpleegd op 4 april 2019.

Steinmetz, S. (2016). Asterdorp: een Amsterdamse geschiedenis van verheffing en vernedering. Amsterdam: Atlas Contact.

Terrion, J.L. (2006). Building social capital in vulnerable families: Success markers of a school-based intervention program. Youth \& Society, 38 (2): 155-176.

Tonkens, E., \& Wilde, M. de (red.) (2013). Als meedoen pijn doet. Affectief burgerschap in de wijk. Amsterdam: Van Gennep. 
Uitermark, J. (2003). 'Social Mixing' and the Management of Disadvantaged Neighbourhoods: The Dutch Policy of Urban Restructuring Revisited. Urban Studies, 40 (3): 531-549.

Uitermark, J. (2009). An in memoriam for the just city of Amsterdam. City, 13 (2-3).

Uitermark, J. (2014). Integration and Control: The Governing of Urban Marginality in Western Europe. International Journal of Urban and Regional Research, 38 (4), 1418-1436.

Uyterlinde, M., \& Engbersen, R. (2018). Zijn vitale wijken maakbaar? Essay Kenniswerkplaats leefbare wijken Rotterdam. Den Haag: Platform 31.

Veldboer, L., \& Duyvendak, J.W. (2001). Integratie en de multiculturele samenleving: over mengen, spreiden en ontmoeten. In: J. W. Duyvendak \& L. Veldboer (red.), Meeting Point Nederland. Over samenlevingsopbouw, multiculturaliteit en sociale cohesie. Amsterdam: Boom, 51-74.

Veldboer, L, Duyvendak, J.W., \& Bouw, C. (red.) (2007). De mixfactor: integratie of segregatie in Nederland. Amsterdam: Boom.

Vermeij, L., \& Kullberg, J. (2015). Niet van de Straat. De lokale samenleving in globaliserende, groeiende steden. Den Haag: Sociaal en Cultureel Planbureau.

VROM-raad (2006). Stad en stijging: sociale stijging als leidraad voor stedelijke vernieuwing. Den Haag: De Raad voor de Volkshuisvesting, de Ruimtelijke Ordening en het Milieubeheer.

Wekker, F. (2017). Top-down Community Building and the Politics of Inclusion. Londen/New York: Palgrave Macmillan.

Welschen, S. (2014). White Working Class Communities in Amsterdam. Open Society Foundations.

Wijdeven, T. van de (2012). Doe-democratie: Over actief burgerschap in stadswijken . Eburon Uitgeverij BV.

Wilk, D. van der (2016). Van wie is het Plein? Over de (on)toegankelijkheid van de openbare ruimte in een gentrificerende buurt te Amsterdam (doctoraatsthesis, afdeling Sociologie, Universiteit van Amsterdam).

Woolcock, M. (2001). The place of social capital in understanding social and economic outcomes. Canadian Journal of Policy Research, 2 (1): 11-17.

WRR (2005). Vertrouwen in de buurt.. Amsterdam/Den Haag: Amsterdam University Press/ Wetenschappelijke Raad voor het Regeringsbeleid.

Ypeij, A., Snel, E., \& Engbersen, G. (2002). Armoede in Amsterdam-Noord. Eerste deelstudie van project 'Landschappen van armoede'. Rotterdam: RISBO Contractresearch BV/Erasmus Universiteit Rotterdam.

Zukin, S. (2010). Naked City: The Death and Life of Authentic Urban Places. Oxford: Oxford University Press.

Zwaard, J. van der (2010). Ontmoetingen in de Copy Corner. In kopieerwinkel de Copy Corner in Rotterdam komen mensen elkaar vanzelfsprekend tegen, en worden ze herkenbaar, vertrouwd en benaderbaar voor elkaar. Tijdschrift voor de Sociale Sector, (5): 12. 